\title{
Introduction to heritage and identity: from planning and policies to communities, and back
}

Remi Wacogne

In this section, you will find four chapters that explore cases around the theme of identity in heritage planning. While the chapters share the general assumption that identity and heritage planning are strongly interrelated, they all address rather different governance scales, management concepts and heritage perspectives dealing with the built environment. Ranging from urban heritage sites to cultural landscapes, the chapters consider places both as landscapes, characterized by specific morphologies, values and practices, and as the contexts for various traditions, operations and activities.

Archaeological sites raise specific issues for conservation, management, accessibility and interpretation, as much as post-industrial areas do; also, Europe as a whole is said to be a landscape characterized by a distinctive heritage. At that level, while heritage is constantly promoted as something shared by all Europeans, and as such as a key element of a common identity (see, for instance, Navracsics 2018), heritage appears as a complex issue of law and policy. While the first three chapters focus on experiments in heritage management, they shed light on national and local contexts, which often raise as many new challenges as they provide opportunities. The last chapter suggests that the same is true at the European Union (EU) level. In that sense, this section suggests that heritage professionals from all backgrounds and institutional contexts shouldn't be too satisfied with the celebratory tone adopted throughout the European Year of Cultural Heritage, but should rather question the aims and outcomes of their practices.

Significantly, the EU itself has substantially financed a project dedicated to 'The Role and Spatial Effects of Cultural Heritage and Identity' (Dynamo Trans-National Group 2006). This identified the following as 'cultural heritage 
and identity components': 'monuments, protected cultural landscapes and conjuncts, museums and galleries, events, cultural diversity, cultural professionals, cultural infrastructure and organizations, intellectual capital, and cultural excellence'. While such an approach promoted the role of planning, it somewhat downplayed that of local communities, in spite of the recent adoption of the European Landscape and Faro Conventions. However, as already suggested by Hague and Jenkins (2005), how to deal with heritage and identity in landscape and urban heritage management seems to be the key challenge, and heritage practices could still learn from much of the theory that has been developed in relation to both concepts over the last two decades, as much singularly as concurrently.

Although heritage was only incidentally addressed by Manuel Castells in his extensive inquiry into The Power of Identity (2008), his conclusion that 'there is, worldwide, an increasing tension between political participation, social demands, and the responsiveness of democratic institutions' (p. 411) is critical for this field. Laurajane Smith's influential analysis of the Uses of Heritage (2006), still at a global level, unveiled the similar power of heritage sites and items, which commonly serve discourses and operations of appropriation and protest, either from 'experts' or local communities. Since then, several volumes, edited by at least two different authors and collecting diverse contributions, have been dedicated to the relationship between heritage and identity, suggesting that this issue can hardly be addressed from a single perspective. First, Ashworth et al. (2007) emphasized how much heritage is an expression of plurality and, as such, provides a key opportunity to foster pluralism in our multicultural societies. This postcolonial perspective, which had been introduced, for instance, by Hall (1999), was shared by the editors and authors of another key publication, which summarized 'the interconnections between two slippery and ambiguous yet dynamically important concepts' of heritage and identity (Graham and Howard 2008, 1). Aiming to reassess the 'affective qualities' of heritage over its appreciation within discourses and representations in critical interdisciplinary heritage studies, Harrison (2012) addressed the unprecedented abundance of heritage nowadays and argued for the necessity of promoting 'connectivity' and 'dialogue'. Where do we stand now? Have practices and contexts evolved much since Stuart Hall (1999) asked 'Whose heritage?'

The chapters in this section suggest that engagement in heritage has made little progress in general, although they acknowledge significant efforts in that direction. For instance, new approaches and tools have been developed to make up for the challenges that archaeological sites raise in that sense. Thus, in the first chapter of the section, Tom Moore and Gemma Tully present and 
discuss the results of a comparative analysis of four oppida sites, situated in England, France and Spain. As archaeological sites, these can be 'participatory landscapes' only through a strong commitment from their management systems, which have demonstrated a certain capacity to engage with local communities. Rather than a challenge pertaining to heritage assets' typical 'nature', this might then be a question of management and governance, approaches and tools.

The next chapter by Loes Veldpaus and Remi Wacogne deals with urban heritage. It shows how public austerity measures have corresponded to significant evolutions in that sense. Based on four case studies carried out as part of the PICH project in former industrial areas in England, Italy, Norway and the Netherlands, it analyses recent shifts from public to private and from government to governance, with increasingly important roles for 'other-than-public' actors in partnerships. Although regulation and management, as well as issues including decontamination of brownfield areas, characterize former industrial sites as a special type of urban heritage, they offer significant insights into the governance of the built environment in general. In particular, the authors highlight how local communities, including former workers, are generally left out of conservation-planning processes.

By providing 4D reconstructions of heritage assets no longer existing in their original and successive forms, the $\mathrm{CHT} 2$ project has proved to be a compelling experiment in the use of digital technologies. This is evoked in the following chapter by Laura Loredana Micoli, Gabriele Guidi, Pablo Rodríguez-Gonzálvez and Diego González-Aguilera. Moreover, it is demonstrated that such technologies are an opportunity not only in terms of interpretation of heritage (tangible and intangible) and public accessibility, but also as a means to engage local communities.

Finally, in the last chapter in this section, Francesca Fiorentini, Kristin Hausler and Andrzej Jakubowski discuss the findings of the HEURIGHT project, dealing with the tension between member states and the EU bodies in that field as expressed, for instance, by Brexit, but also by the setback in Italy's ratification of the Faro Convention. Here also, recent changes in the social, political and economic fields are identified as key challenges for heritage and planning; the authors argue that the legal and policy framework at the EU level needs to be further systematized and made more balanced as well as more inclusive.

Remarkably, despite the authors' diverse backgrounds, objects and aims, all the chapters share the view that only through the engagement of all categories of stakeholders can heritage be managed in a sustainable way. If some of the 
writers differ in their assumptions about identity as a concept, they concur in showing that places are constantly shaped at once physically, affectively and ideally by communities, and as such should be planned considering 'ordinary' people's practices and values, either as residents, users or visitors, in relation to their environments. Thus, while 'the existence of a common European cultural heritage should not be taken for granted', as argued in the last chapter in this section, all four chapters suggest that 'to keep bringing European cultural heritage to the forefront' (Navracsics 2018) implies its effective integration within planning and policies (see also Pendlebury 2015) but also, and maybe more critically, a strong stance in favour of communities rather than identities (see also Pendlebury and Veldpaus 2018).

\section{References}

Ashworth, G.J., B.J. Graham and J.E. Tunbridge (2007), Pluralising Pasts: Heritage, Identity and Place in Multicultural Societies, London: Pluto.

Castells, M. (2004), The Power of Identity, Malden, MA: Blackwell.

Dynamo Trans-National Group (2006), The Role and Spatial Effects of Cultural Heritage and Identity (2004-2006). Executive Summary (ESPON project 1.3.3), co-financed by the European Community through the Interreg 18 ESPON Programme. Accessed 10 May 2021 at: https://www.espon.eu/sites/default/files/attachments/1.ir_1.3.3-full .pdf.

Graham, B. and P. Howard (eds) (2008), The Ashgate Research Companion to Heritage and Identity, Aldershot and Burlington: Ashgate.

Hague, C. and P. Jenkins (2005), Place Identity, Participation and Planning, London: Routledge.

Hall, S. (1999), "Whose heritage? Un-settling "the heritage", re-imagining the Postnation', Third Text, 13 (49), 3-13, doi: 10.1080/09528829908576818.

Harrison, R. (2012), Heritage: Critical Approaches, London: Routledge.

Navracsics, T. (2018), 'Exploring heritage and identity - towards embracing a European identity', opening speech delivered at the Interpret Europe Conference on 'Heritage and Identity', held in Koszeg, Hungary, 23 March 2018. Accessed 10 May 2021 at: https://iask.hu/en/heritage-and-identity-interpret-europe-conference/.

Pendlebury, J. (2015), 'Heritage and policy', in E. Waterton and S. Watson (eds), The Palgrave Handbook of Contemporary Heritage Research, London: Palgrave Macmillan, 426-41.

Pendlebury, J. and L. Veldpaus (2018), 'Heritage and Brexit', Planning Theory and Practice, 19 (3), 448-53.

Smith, L. (2006), Uses of Heritage, London: Routledge. 